\title{
POLEMIK ISBAL DAN SOMBONG SERTA PENDAPAT ULAMA TERKAIT MUKHTALIF AL HADITS
}

\author{
Armansyah, M.H. \\ Sekolah Tinggi Ilmu Syari'ah (STIS) AL-Amin Bima \\ armansyah19.boro@gmail.com
}

\section{Abstrak}

Dalam beberapa kajian ilmu khususnya kajian keislaman, seringkali masyarakat mendengar beberapa pendapat yang berbeda-beda terhadap masalah yang sama dari seorang ustadz atau ulama yang menyampaikan. Hal ini sering kali menjadikan masyarakat awam, khususnya yang baru belajar menjadi bingung pendapat mana yang harus digunakan. Maka sudah seharusnya seorang ustadz atau ulama yang menyampaikan bersikap bijak dengan menyebutkan semua yang ia ketahui tertang hal yang ditanyakan, termasuk perbedaan yang terjadi dalam hal tersebut jika ada. Dengan demikian, ketika masyarakat awam menemukan orang lain yang melakukan sesuatu yang berbeda dengan yang ia yakini maka tidak dengan mudahnya menghukumi, menyalahkan apalagi sampai mencaci sehingga menyebabkan terputusnya silaturrahim yang diharamkan oleh Allah Swt. dan Rasul-Nya. Termasuklah permasalahan yang hendak di angkat oleh penulis di sini, yaitu tentang isbal (memanjangkan kaki celana hingga menutupi mata kaki), karena menurut hemat penulis masih banyak di antara kaum intelektual sekalipun belum memahami secara utuh tentang hal tersebut. Beberapa di antaranya menganggap sudah tidak relefan dengan zaman, kadaluarsa 
dan lain sebagainya, sebagian lain menganggap hal tersebut adalah sesuatu yang harus dilaksanakan atau wajib sehingga ketika tidak melakukannya dianggap berdosa bahkan di anggap thagut. Na'udzubillah. Selain itu, ada kata sombong yang diungkapkan Rasulullah Saw. dalam hadits riwayat Shahih al Bukhâri, Shahih Muslim, Al Tirmidzi, Al Nasâi, Abu Daud, Ibnu Mâjah, Ahmad bin Hanbal, Imam Mâlik, dan Al Dârimî. , apa makna didalamnya, apakah semua pelaku atau ada kriteria lain?, dan terakhir penulis hendak menjelaskan tentang mukhtalif al hadits terkait masalah isbal.

\section{Keyword: Isbal, Sombong, Mukhtalif al Hadits}

\section{A. Pendahuluan}

Menurut kesepakatan mayoritas (jumhur) ulama bahwa sumber pokok pengambilan kesimpulan hukum (istinbath) dalam islam terdiri dari empat, yaitu; Alquran, Hadits, Ijma' dan Qiyas. Walaupun sebagian ulama lain menambahkan dengan beberapa sumber lain, yaitu; Istihsan dan Istishab, Syar'u man qablana, Fi'lu wa qaul al shahabi, ishtislah (mashaleh mursalah), saddu dzari'ah dan 'urf.

Oleh banyaknya sumber-sumber hukum tersebut khsusunya Alquran dan hadits, penulis sendiri menyimpulkan beberapa hal terkait dalil-dalil tersebut:

1. Adakalanya antara dalil satu dengan yang lainnya saling menguatkan, Alquran menyebutkan suatu hukum, lalu hadits menguatkannya atau sebaliknya. Contohnya seperti kewajiban melaksanakan shalat 5 waktu, Allah Swt. berfirman:

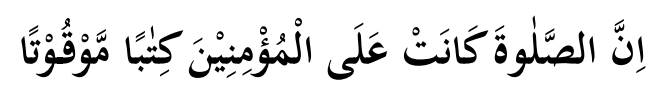


Terjemahnya:

"Sungguh, shalat itu adalah kewajiban yang ditentukan waktunya atas orang-orang yang beriman." (QS. Al Nisa: 103)

Kemudian dikuatkan oleh hadits Rasulullah Saw.:

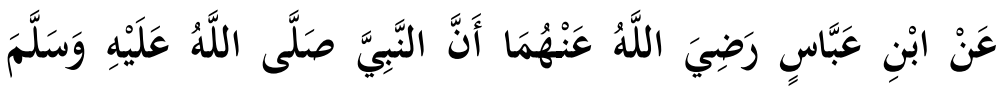

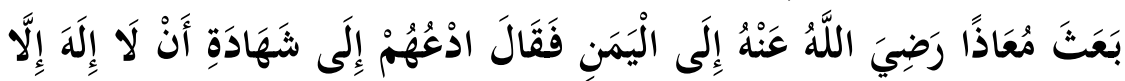

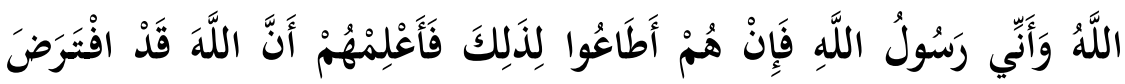

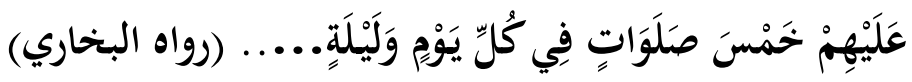

Artinya:

Dari Ibnu Abbas bahwasannya Nabi Saw. telah mengutus Muadz ke Yaman, lalu beliau bersabda kepadanya "Ajaklah mereka (penduduk Yaman) untuk bersaksi bahwa tidak ada Tuhan selain Allah dan sungguh aku adalah utusan Allah, jika mereka menaatinya, maka beritahukan mereka bahwa Allah telah mewajibkan kepada mereka lima shalat dalam sehari semalam...." (HR. Al Bukhari)

2. Adakalanya antara dalil satu dengan yang lainnya saling bertentangan. Hadits yang satu membolehkan dan hadits lain melarang atau mengharamkannya. Contohnya seperti, penjelasan Rasulullah Saw. tentang air, beliau bersabda:

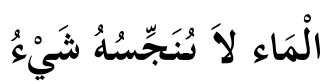

Artinya:

"Air tidak bisa dinajiskan oleh siapapun." (HR. Ibnu Majah)

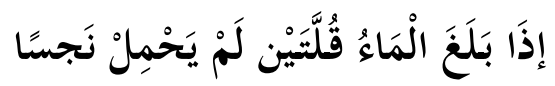

Sangaji Jurnal Pemikiran Syariah dan Hukum 


\section{Artinya:}

"Jika air telah mencapai dua qulah, maka tidak akan membawa najis." (HR. Abu Dawud, Tirmidzi, Nasa'i, dan Ibnu Majah dan dishahihkan oleh Ibnu Khuzaimah, dan Al Hakim dan Ibnu Hibban).

Sekilas dua hadis tersebut tampak bertentangan, namun hadits tersebut dapat dikompromikan hingga tidak terjadi pertentangan. Ibnu Qutaibah mengatakan, Rasulullah Saw. menyabdakan hadits pertama berdasarkan kebiasaan dan yang paling banyak terlihat. Karena pernyataan beliau tersebut merupakan kekhususan. Dengan demikian ukuran air dua kulah, suatu ukuran yang tidak dapat dinajiskan. ${ }^{1}$

3. Dalam fatwa ulama (Ijma'), fatwa ulama pertama membolehkan, fatwa ulama kedua menggapnya sunnah, dan fatwa ulama lain menganggapnya mubah atau makruh bahkan haram. Contohnya seperti dalam menyentuh wanita bukan mahram; ${ }^{2}$

a) Imam Abu Hanifah dan para pengikutnya menyebutkan bahwa persentuhan kulit laki-laki dan perempuan tidak membatalkan wudhu secara mutlak, baik dengan syahwat atau tidak. Hal ini berdasar pada hadits riwayat Aisyah:

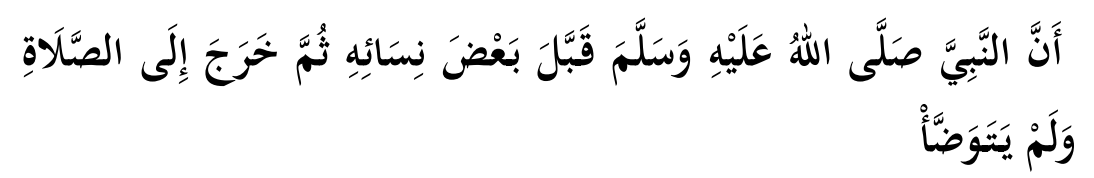

1 Muhammad Gufron. 2013. Ulumul Hadis Praktis dan Mudah. Yogyakarta: Teras. Hlm. 80-81.

2 Muhammad Ali al-Shabuni1980. Rawa'i al Bayan Tafsir Ayat al Ahkam min al Qur'an. Damaskus: Maktabah al Ghazali. Hlm. 487-488. 
Artinya:

"Bahwa Nabi Saw. mencium beberapa istrinya lalu keluar untuk shalat, tanpa berwudhu." (HR. Al Tirmidzi).

b) Sedangkan Imam Al Syafi'i dan para pengikutnya menegaskan bahwa persentuhan kulit tersebut dapat membatalkan wudhu, baik dengan syahwat atau tidak. Hal ini berpedoman pada makna zhahir Surat al Nisa ayat 43 di atas, yaitu firman Allah Saw.:

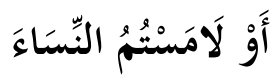

Terjemahnya:

"Atau kamu telah menyentuh perempuan." (QS. Al Nisa: 43)

Kelompok ini mengatakan, makna hakiki dari kata "al lamsu" adalah menyentuh dengan tangan, sedangkan makna majazinya adalah berhubungan badan. Selama perkataan bisa diartikan dengan makna hakiki, maka tidak boleh diartikan dengan makna majazi, kecuali jika tidak mungkin menggunakan makna hakiki, sebagaimana kaidah:

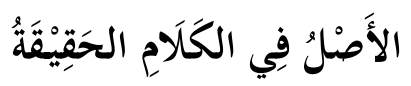

Artinya:

"Pada dasarnya, ucapan itu bermakna hakiki."

c) Dan Imam Malik serta para pengikutnya memberikan rincian; jika persentuhan itu di ikuti dengan syahwat maka membatalkan wudhu, tetapi jika tanpa syahwat, tidak membatalkan. Kelompok ini mencoba menggabungkan dan mencari titik temu antara haditshadits yang dijadikan sandaran oleh kelompok pertama, dan ayat Alquran yang dijadikan landasan oleh kelompok kedua. Kemudian menyimpulkan bahwa persentuhan kulit yang disertai syahwat dapat

Sangaji Jurnal Pemikiran Syariah dan Hukum 
membatalkan wudhu, berdasarkan ayat tersebut, dan tidak membatalkan wudhu jika tidak disertai syahwat, berdasarkan hadits-hadits dimaksud.

Maka demikian pula dengan topik yang di angkat oleh penulis, ada beberapa hadits yang memiliki satu tujuan namun juga memiliki redaksi yang berbeda-beda, sehingga menimbulkan perbedaan pendapat para ulama fikih dalam menyimpulkan hukumnya.

\section{B. Pembahasan}

\section{Pengertian Isbal}

Sebelum terlalu jauh membahas tentang hukum isbal dan beberapa pandangan dan kesimpulan ulama terkait haditshadits isbal, sedikt penulis menjelaskan tentang pengertian isbal itu sendiri, dalam kamus arab "Lisan al Arab" karya Ibnu Mundzir dijelaskan:

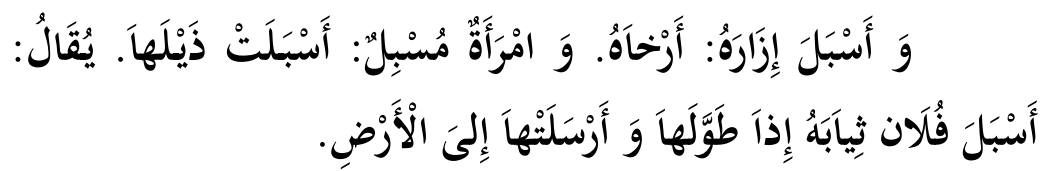

Artinya:

"Ia telah meng-isbal kainnya: menggeraikannya. Seorang perempuan yang Musbil: ia telah memanjangkan pakaiannya. Dikatakan: seseorang telah mengisbal pakaiannya apabila ia memanjangkannya, dan menggeraikannya hingga menyeret tanah"3 $^{\prime \prime}$

Dalam hadits tentang isbal ini, ditemukan kata lain, yaitu "جَرَّ" yang dalam kamus arab "Lisan al Arab" karya Ibnu Mundzir dijelaskan:

${ }^{3}$ Ibn Munzir. 1119. Lisan al 'Arab, Juz. 21. Kairo: Dar al Ma'arif. Hlm. 1930. 


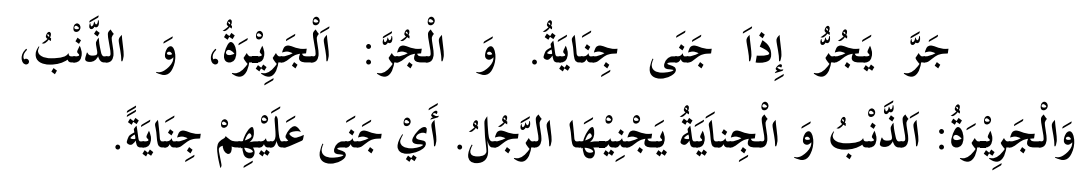

Artinya:

"Ia menarik, mengalirkan, menjalankan, membiasakan diri dalam melakukan kesalahan atau dosa. Mengalirkan: Membiasakan diri, dan mengalirkan: Perbuatan dosa atau kriminal yang biasa dilakukan oleh laki-laki, atau telah terbiasa melakukan dosa dalam dirinya secara berkepanjangan"4

Maka dari uraian kalimat dan pengertian di atas dapat disimpulkan bahwa pengertian isbal secara umum adalah memanjangkan atau menguraikan kain atau sarung di bawah mata kaki dengan maksud ataupun tidak dengan maksud sombong. Dan dapat juga dipahami bahwa orang yang terbiasa dalam dalam berbuat kesalahan berarti itu telah menunjukkan tentang kepribadian seseorang tersebut. Maka dapat dikatakan juga bahwa seseorang yang terbiasa memanjangkan pakaian dan atau sarungnya dapat juga dikatakan bahwa ia memang memiliki kepribadian yang suka memanjang-manjangkan sesuatu dan berlebihan.

\section{Hadits-Hadits Tentang Isbal}

Terkait isbal, terdapat banyak sekali hadits-hadits yang membahas dan menjelaskannya, namun penulis hanya akan mengangkat beberapa diantaranya saja dengan mengelompokkannya dalam tiga bagian:

a) Larangan isbal secara umum

\section{Hadits pertama}
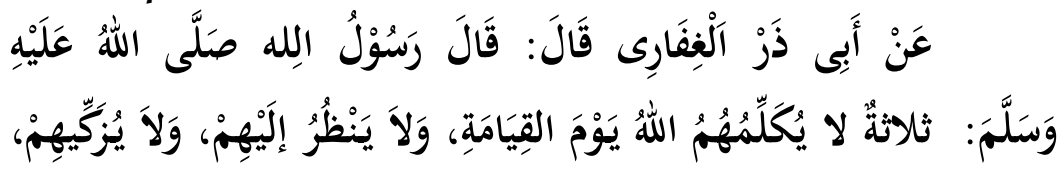

${ }^{4}$ Ibn Munzir. 1119. Lisan al 'Arab, Juz. 21. Kairo: Dar al Ma'arif. Hlm. 594.

Sangaji Jurnal Pemikiran Syariah dan Hukum 


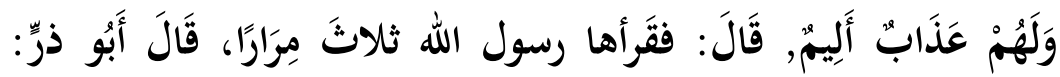

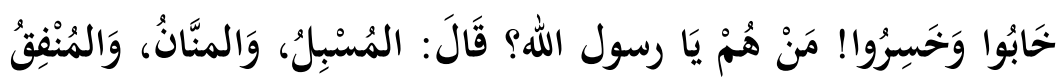

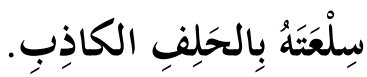

Artinya:

Dari Abu Dzar, Rasulullah bersabda: "Ada tiga golongan yang tidak akan diajak bicara oleh Allah pada hari Kiamat kelak, tidak dilihat, tidak disucikan dan mereka akan mendapat siksa yang sangat pedih." Ia berkata: "Rasulullah mengucapkannya sebanyak tiga kali." Abu Dzar bertanya: "Sungguh sangat jelek dan merugi mereka itu. Siapa mereka itu wahai Rasulullah?" Beliau menjawab: "Musbil (orang yang menjulurkan kain hingga di bawah mata kaki), orang yang gemar mengungkit kebaikan yang telah ia berikan dan seorang yang menjual dagangannya dan bersumpah dengan sumpah palsu." (HR. Muslim, Abu Daud, Al Nasa'i dan Al Darimi) ${ }^{5}$

\section{Hadits kedua}

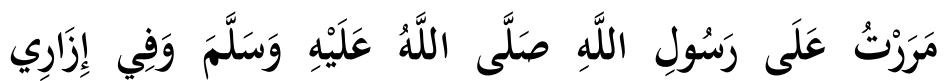

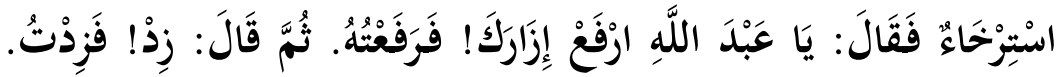

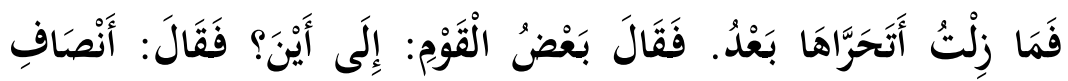
السَّاقَيْنِ

Artinya:

Aku (Ibnu Umar) pernah melewati Rasulullah Saw., sementara kain sarungku terurai (sampai ke tanah). Beliau pun bersabda, "Hai Abdullah, naikkan sarungmu!". Aku pun langsung menaikkan kain

${ }^{5}$ Imam Abi al Husain Muslim Ibn Hajjaj. 1992. Mausu'ah al Sunnah al Kutub al Sittah wa Syuruhuha, Jld. II. Cetakan II. Istanbul: Daar Sahnun. Hlm. 465. 
sarungku. Setelah itu Rasulullah bersabda, "Naikkan lagi!" Aku naikkan lagi. Sejak itu aku selalu menjaga agar kainku setinggi itu." Ada beberapa orang yang bertanya, "Sampai di mana batasnya?" Ibnu Umar menjawab, "Sampai pertengahan kedua betis." (HR. Muslim)

\section{Hadits ketiga}

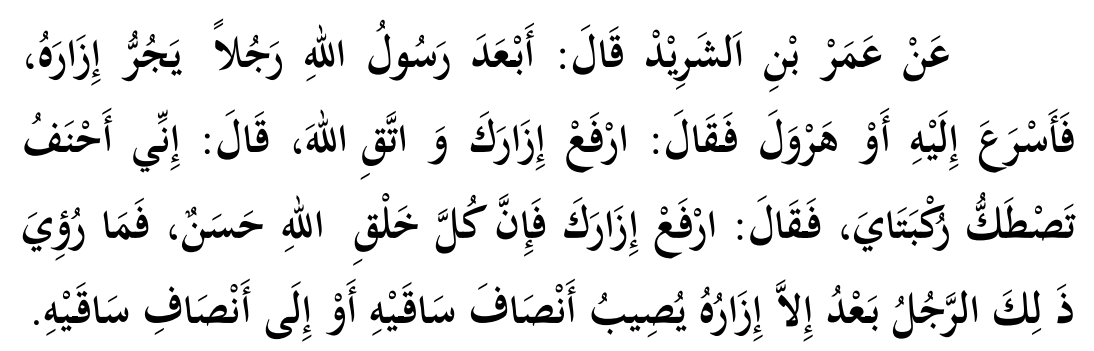

Artinya:

Dari Amr bin Al Syarid berkata: Dari kejauhan Rasulullah Saw. melihat seorang laki-laki yang menjulurkan kain sarungnya hingga terseret. Maka beliaupun bergegas untuk menjumpainya, atau beliau berlari-lari kecil menuju orang tersebut. Lalu beliau menegurnya: "Angkatlah kain sarungmu dan bertaqwalah kepada Allah." Maka orang itupun berkata: "Sesungguhnya saya seorang yang memiliki kaki bengkok dan kedua lutut saya berbenturan ketika berjalan." Ternyata Rasulullah tetap mengatakan: "Angkatlah kain sarungmu, karena sesungguhnya semua ciptaan Allah adalah bagus." Maka setelah kejadian itu tidaklah nampak laki-laki tersebut melainkan kain sarungnya senantiasa terangkat hingga pada tengah-tengah kedua betisnya atau di bawahnya sedikit." (HR. Ahmad, Al Humaidi dan Al Thahawi, dishahihkan Al Albani)

Sangaji Jurnal Pemikiran Syariah dan Hukum 


\section{Hadits keempat}

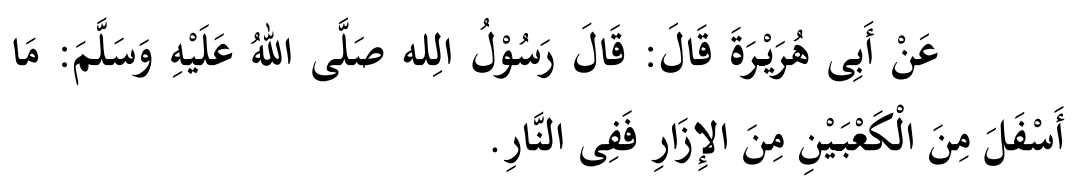

Artinya:

Dari Abu Hurairah, Rasulullah bersabda, "Kain yang berada di bawah mata kaki itu berada di neraka." (HR. Bukhari dan Ahmad)

b) Larangan isbal ketika shalat

\section{Hadits pertama}

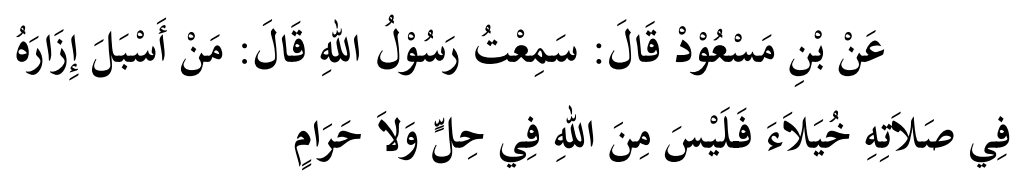

Artinya:

Dari Abdullah bin Mas'ud, ia berkata: "Aku pernah mendengar Rasulullah bersabda: "Barangsiapa menjulurkan kain sarung dengan sombong di dalam shalatnya maka Allah Swt. tidak akan menghalalkan dan tidak mengharamkan." (HR. Abu Daud dan dishahihkan Al Albani)

\section{Hadits kedua}

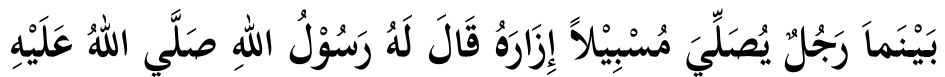

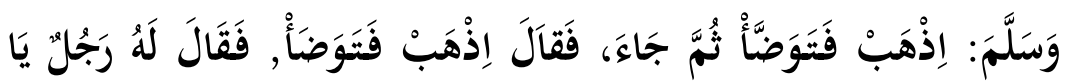

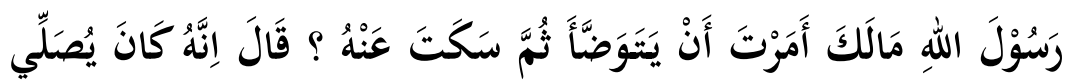

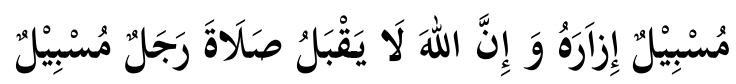

Artinya:

Ketika ada seorang laki- laki yang sedang shalat dengan kain sarungnya yang berada di bawah mata 
kaki, maka Rasullullah Saw. berkata kepadanya, "pergilah berwudhu", lelaki itupun pergi berwudhu dan sesudah berwudhu, Nabi Saw. berkata lagi, "pergilah berwudhu", maka seorang bertanya "Wahai Rasulullah mengapa engkau menyuruh dia berwudhu, maka setelah berwudhu engkau diamkan dia?" Nabi Saw. Menjawab: “dia telah shalat dengan sarung di bawah mata kaki, dan Allah Swt. tidak menerima shalat seseorang yang kain sarungnya dibawah mata kaki." (HR Abu Daud , Ainul Mabud 11/133).

c) Larangan isbal karena adanya illat, sombong.

Hadits pertama

عَنْ عَبْدِ الله بْنُ عُمَرْ، قَالَ رَسُوْلُ اللَهِ صَلَّى اللهُ عَلَيْيْهِ وَسَلَّمَ:

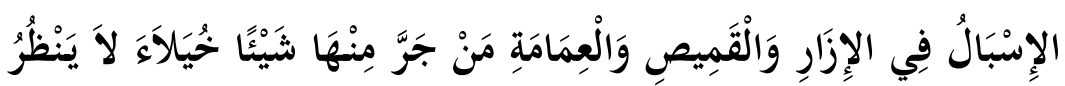

اللهُ إلِيَِّْ يَوْمَ الْلِيَامَةِّ.

Artinya:

Dari Ibnu Umar, Rasulullah Saw.bersabda: "Isbal itu ada pada kain sarung, baju panjang dan sorban. Barangsiapa memanjangkannya karena sombong maka Allah Swt. tidak akan melihatnya pada hari kiamat kelak." (HR. Abu Daud, Al Nasa'i, Ibnu Majah dan dishahihkan Al Albani)

\section{Hadits kedua}

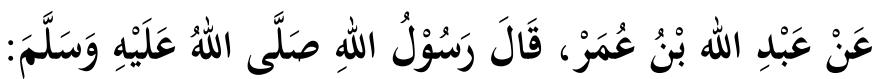

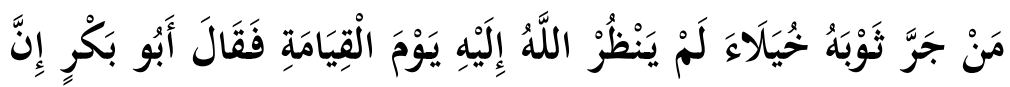

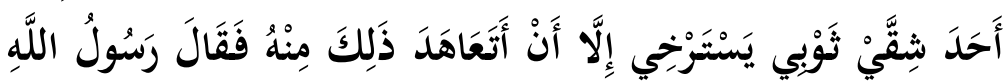

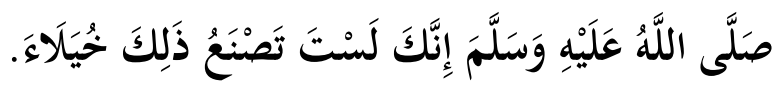

Sangaji Jurnal Pemikiran Syariah dan Hukum 
Artinya:

Dari Abdullah bin Umar, Rasulullah Saw. bersabda: "Siapa yang menyeret kainnya karena sombong, maka Allah Swt. tidak akan melihatnya." Kemudian Abu Bakar bertanya: "Wahai Rasulullah, sesungguhnya satu bagian (ujung) dari kainku menjulur. Kecuali aku harus terus menjaganya agar tidak menjulur." Rasulullah bersabda: "Kamu tidak termasuk orang yang melakukannya dengan sombong." (HR. Al-Bukhari dan Muslim)

\section{Hadits ketiga}

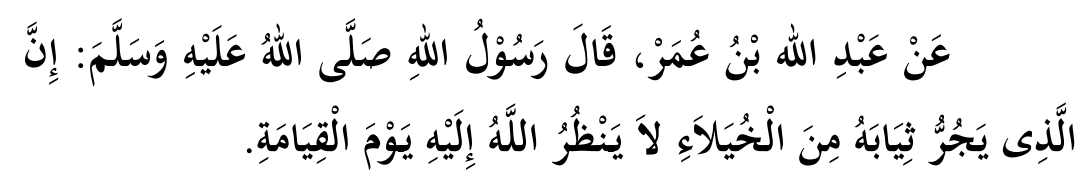

Artinya:

Dari Ibnu Umar, Rasulullah Saw. bersabda : "Sesungguhnya orang yang menyeret pakaiannya dengan sombong, Allah Swt. tidak akan melihatnya pada hari kiamat." (HR. Bukhari dan Muslim) ${ }^{6}$

\section{Hadits keempat}

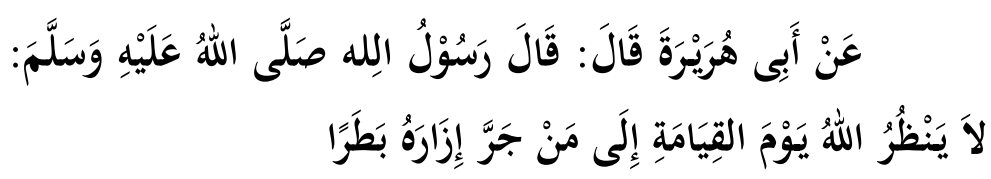

Artinya:

Dari Abu Hurairah, Rasulullah Saw. bersabda: "Allah tidak akan melihat kepada orang yang menjulurkan kain sarungnya karena kesombongan." (HR. Al Bukhari dan Muslim)

${ }^{6}$ Imam Abi Abdillah Muhammad Ibn Isma'il Al Bukhari, Mausu'ah al Sunnah al Kutub al Sittah wa Syuruhuha, Jld. VII (Istanbul: Daar Sahnun, Cet. II 1413 H/1992 M), hlm. 254. 


\section{Perbedaan Pendapat Ulama Tentang Isbal}

Dari beberapa hadits yang disebutkan di atas, maka penulis menemukan beberapa perbedaan pendapat ulama dalam pengambilan hukum (istinbath al ahkam) terkait masalah isbal (menjulurkan kain hingga menutupi mata kaki).

Hadits-hadits di atas secara lahiriah dianggap bertentangan oleh beberapa ulama. Hal tersebut wajar terjadi karena dalam hadits tersebut memberikan peluang untuk dipahami secara berbeda. Mengacu kepada teks matan hadits tersebut yang didalamnya mengungkap tentang ketercelaan bagi orang yang isbal. Hanya saja, beberapa hadits tidak membatasi dalam teksnya tentang perbuatan isbal tersebut, sementara di hadits lain dibatasi dengan lafadz khuyalâ dan bathara. Dari sinilah pokok permasalahan sehingga terjadi kontroversi.

Sebagaimana yang diungkapkan oleh M. Syuhudi Ismail dan di kutip kembali oleh Muhammad Nasir ${ }^{7}$ dalam tulisannya, "Kontroversi Hadis-Hadis Tentang Isbal" mengatakan bahwa Ketika terjadi pertentangan antara dua hadits, ulama dalam menyelesaikan permasalahan tersebut menempuh cara yang berbeda-beda; ada yang menempuh satu cara dan ada yang menggunakan beberapa cara dengan berbeda urutannya. Berikut ini adalah cara yang ditempuh ketika terjadi pertentangan dalil yaitu :

a) Al Jam'u yaitu kedua hadits yang bertentangan dikompromikan.

b) Al Nasikh wa al Mansukh

c) Al Tarjih (menentukan hadits yang lebih kuat)

7 Muhammad Nasir. 2013. Kontroversi Hadis-Hadis Tentang Isbal: Telaah Kritis Sanad dan Matan Hadis serta Metode Penyelesainnya. Jurnal Farabi Vol. 10 No. 1 Juni 2013. Hlm. 94.

Sangaji Jurnal Pemikiran Syariah dan Hukum 
d) Al Tauqif (menunggu sampai ada dalil yang lain yang dapat menyelesaikan pertentangan tersebut.

Maka, dalam hal ini setidaknya ada dua pendapat yang berbeda dalam memahami hadits-hadits di atas:

a) Pendapat yang tidak membolehkan isbal secara mutlak. Pendapat ini ber-hujjah dengan beberapa dalil; baik naqli (Alquran dan hadits) maupun secara aqli (akal);

1) Dalil naqli dari hadits

Yaitu hadits yang diriwayatkan oleh Abu Dzar al Ghifari tentang tiga golongan yang tidak di ajak bicara, tidak di lihat, tidak disucikan mendapat adzab di hari kiamat. ${ }^{8}$

عَنْ أَبَى ذَزْ آلْفِفَارِى قَالَ: قَالَ رَسُوْلُ اللهه صَلَّلَى اللهُ عَلَيْهِهِ وَسَلَّمَ:

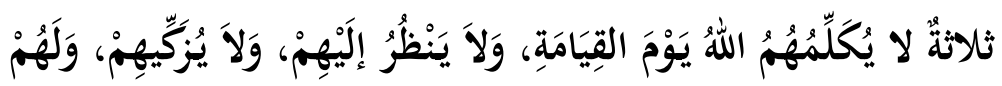

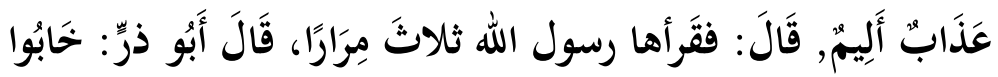

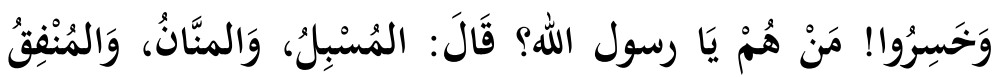

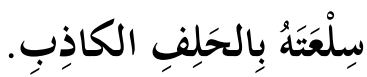

Maka dapat dimaknai secara langsung dari hadits ini bahwa salah satu penyebab orang akan di adzab oleh Allah Swt kelak adalah mamanjangkan kain hingga menutupi mata kaki.

Dalil kedua adalah hadits riwayat Abu Hurairah; ${ }^{9}$

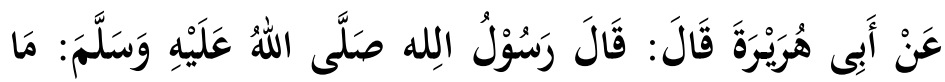

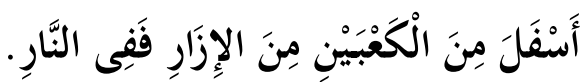

8 Lihat: Hadits Riwayat Muslim 106, Abu Dawud 4087, Nasa'i 4455, Darimi 2608.

${ }^{9}$ Lihat: Hadits Riwayat Bukhari 5797, Ibnu Majah 3573, Ahmad 2/96. 
Dalil ketiga adalah hadits riwayat Abdullah bin Umar, ${ }^{10}$

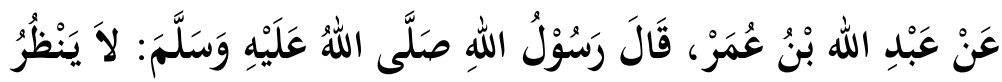

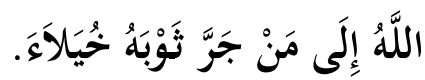

"Barangsiapa yang melabuhkan pakaiannya karena sombong, maka Allah tidak akan melihatnya pada hari kiamat."

Dalil keempat adalah hadits riwayat Abdullah bin Umar juga, ${ }^{11}$

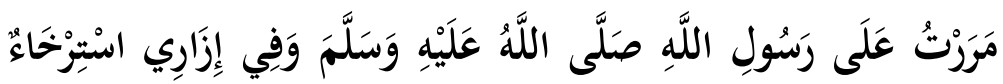

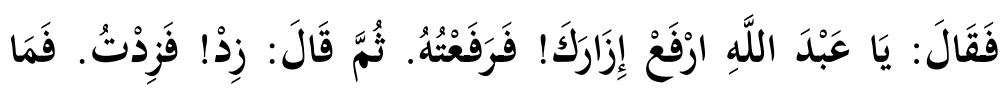

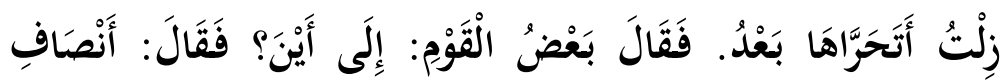
السَّاقَّنْن.

Dan masih banyak lagi hadits-hadits lain yang disebutkan terkait mutlaknya pelarangan isbal oleh kelompok pertama ini.

2) Dalil aqli

Adapun dalil aqli yang disampaikan oleh kelompok pertama ini adalah sebagai berikut:

Menyelisihi Sunnah, Menyelesihi sunnah termasuk perkara yang tidak bisa dianggap enteng dan ringan, karena kewajiban setiap muslim untuk mengamalkan setiap sendi agama dalam segala perkara baik

${ }^{10}$ Imam Abi Abdillah Muhammad Ibn Isma'il Al Bukhari, Mausu'ah al Sunnah al Kutub al Sittah wa Syuruhuha, Jld. VII. Cetakan II. Istanbul: Daar Sahnun. Hlm. 243. Lihat juga: Hadits Riwayat Bukhari 5783, Muslim 2085.

${ }^{11}$ Lihat: Hadits Riwayat Muslim 2086. Ahmad 2/33.

Sangaji Jurnal Pemikiran Syariah dan Hukum 
datangnya dari Alquran atau Sunnah. Allah Saw. berfirman;

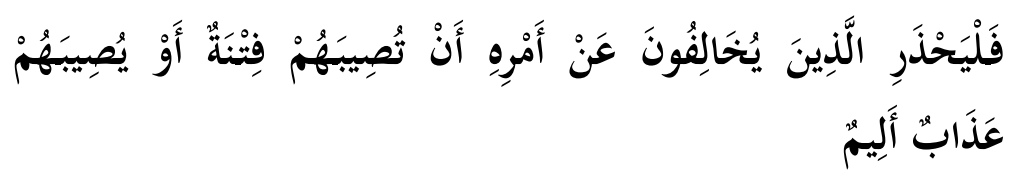

Terjemahnya:

"Maka hendaklah orang-orang yang menyalahi perintah Rasul, takut akan di timpa cobaan (fitnah) atau di timpa adzab yang pedih" (QS. Al Nur: 63)

Termasuk Kesombongan, Berkata Al Hafizh Ibnu Hajar: "Kesimpulannya isbal melazimkan menarik pakaian, dan menarik pakaian melazimkan kesombongan, walaupun pelakunya tidak bermaksud sombong"12. Rasulullah Saw. bersabda : "Waspadalah kalian dari isbal pakaian, karena hal itu termasuk kesombongan, dan Allah tidak menyukai kesombongan". ${ }^{13}$

Menyerupai Wanita, Isbal bagi wanita disyari'atkan bahkan wajib, dan tidak diperkenankan untuk menampakkan anggota tubuh kecuali wajah dan telapak tangan. Orang yang isbal berarti telah menyerupai wanita dalam berpakaian, dan hal itu terlarang secara tegas, berdasarkan hadits riwayat Ibnu Abbas, ia berkata; "Rasulullah melaknat laki-laki yang menyerupai wanita dan wanita yang menyerupai laki-laki". ${ }^{14}$

12 Ahmad bin Ali bin Hajar al Asqalani. 1379. Fathu al Bari; Syarah Shahih al Bukhari, Juz 10. Riyadh: Al Maktabah al Salafiyah. Hlm. 255.

${ }_{13}$ Hadits Riwayat Abu Daud 4084, Ahmad 4/65, dishahihkan oleh Al Albany dalam Al Shahihah 770

14 Lihat: Hadits Riwayat Bukhari 5885, Abu Daud 4097, Tirmidzi 2785, Ibnu Majah 1904. 
Berlebih Lebihan, Tidak ragu lagi syari'at yang mulia ini telah memberikan batas-batas berpakaian, maka barangsiapa yang melebihi batasnya sungguh ia telah belebih-lebihan. Allah Swt. berfirman;

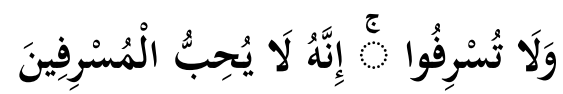

Terjemahnya:

"Dan janganlah berlebih-lebihan. Sesungguhnya Allah Swt. tidak menyukai orang-orang yang berlebih-lebihan" (QS. Al A'raf: 31)

Al Hafizh Ibnu Hajar berkata: "Apabila pakaian melebihi batas semestinya, maka larangannya dari segi israf (berlebih-lebihan) yang berakhir pada keharaman"15

Terkena Najis, Orang yang isbal tidak aman dari najis, bahkan kemungkinan besar najis menempel dan mengenai sarungnya tanpa ia sadari, Rasulullah Saw. bersabda; "Naikkan sarungmu karena hal itu lebih menunjukkan ketakwaan (dalam lafazh yang lain lebih suci dan bersih)". ${ }^{16}$

b) Pendapat yang membolehkan isbal dengan ketentuan tidak karena sombong.

Pendapat ini juga ber-hujjah dengan beberapa dalil; baik naqli (Alquran dan hadits) maupun secara aqli (akal);

1) Dalil naqli dari hadits

Hadits yang diriwayatkan oleh Abdullah bin Umar, Dari Abdullah bin Umar, Rasulullah Saw. bersabda: “Siapa yang menyeret kainnya karena sombong, maka

15 Ahmad bin Ali bin Hajar al Asqalani. 1379. Fathu al Bari; Syarah Shahih al Bukhari, Juz 11. Riyadh: Al Maktabah al Salafiyah. Hlm. 436.

16 Lihat: Hadits Riwayat Tirmidzi dalam Syamail 97, Ahmad 5/364, dishahihkan oleh Al-Albani dalam Mukhtashar Syama'il Muhammadiyyah Hal. 69

Sangaji Jurnal Pemikiran Syariah dan Hukum 
Allah Swt. tidak akan melihatnya." Kemudian Abu Bakar bertanya: "Wahai Rasulullah, sesungguhnya satu bagian (ujung) dari kainku menjulur. Kecuali aku harus terus menjaganya agar tidak menjulur." Rasulullah bersabda: "Kamu tidak termasuk orang yang melakukannya dengan sombong." (HR. Al-Bukhari dan Muslim)

Hadits ini secara tegas mencela perbuatan isbal, tetapi isbal yang dimaksud adalah isbal yang disertai rasa sombong. Bagi orang yang melakukan isbal tetapi dalam hatinya tidak terdapat rasa sombong maka dia tidak termasuk orang yang di cela. Hal ini dapat di lihat dari kasus Abu Bakar sebagaimana yang tercantum dalam hadits di atas.

Hadits yang diriwayatkan oleh Abdullah bin Umar juga, Dari Ibnu Umar, Rasulullah Saw.bersabda: "Isbal itu ada pada kain sarung, baju panjang dan sorban. Barangsiapa memanjangkannya karena sombong maka Allah Swt. tidak akan melihatnya pada hari kiamat kelak."17

Kemudian hadits riwayat Abu Hurairah, Dari Abu Hurairah, Rasulullah Saw. bersabda: "Allah tidak akan melihat kepada orang yang menjulurkan kain sarungnya karena kesombongan."18

\section{Kesimpulan}

Dari penjelasan singkat tentang Polemik Isbal dan Sombong Serta Pendapat Ulama Terkait Mukhtalif al Hadits, ditarik beberapa kesimpulan bahwa: Albani.

17 Lihat: HR. Abu Daud, Al Nasa'i, Ibnu Majah dan dishahihkan Al ${ }^{18}$ Lihat: HR. Al Bukhari dan Muslim. 
1. Terjadi beberapa perbedaan pendapat ulama terkait isbal dalam berpakaian, sebagian ulama memandang bahwa perbuatan tersebut adalah haram secara mutlak dan sebagian lain memakruhkannya.

2. Sebab terjadinya perbedaan pendapat tersebut tidak lain karena memang cara pandang masing-masing ulama yang berbeda dalam memahami hadits.

Sangaji Jurnal Pemikiran Syariah dan Hukum 


\section{Daftar Pustaka}

Gufron, Muhammad. 2013. Ulumul Hadis Praktis dan Mudah. Yogyakarta: Teras.

Al Shabuni, Muhammad Ali. 1980. Rawa'i al Bayan Tafsir Ayat al Ahkam min al Qur'an. Damaskus: Maktabah al Ghazali.

Munzir, Ibn. 1119. Lisan al 'Arab, Juz. 21. Kairo: Dar al Ma'arif. Ibn Hajjaj, Imam Abi al Husain Muslim. 1992. Mausu'ah al Sunnah al Kutub al Sittah wa Syuruhuha, Jld. II. Cetakan II. Istanbul: Daar Sahnun.

Nasir, Muhammad. 2013. Kontroversi Hadis-Hadis Tentang Isbal: Telaah Kritis Sanad dan Matan Hadis serta Metode Penyelesainnya. Jurnal Farabi Vol. 10 No. 1 Juni 2013.

Al Bukhari, Imam Abi Abdillah Muhammad Ibn Isma'il, Mausu'ah al Sunnah al Kutub al Sittah wa Syuruhuha, Jld. VII. Cetakan II. Istanbul: Daar Sahnun.

Al Asqalani, Ahmad bin Ali bin Hajar. 1379. Fathu al Bari; Syarah Shahih al Bukhari, Juz 10. Riyadh: Al Maktabah al Salafiyah. 